\title{
PENGGUNAAN SPATIAL MULTICRITERIA ANALYSIS UNTUK MENENTUKAN DAERAH RAWAN MALARIA DI KABUPATEN PURWOREJO (Application of Spatial Multicriteria Analysis Determining Malaria Vulnarable Area in Purworejo Regerency)
}

\author{
Prima Widayani* dan Erika Yuliantari \\ Departemen Sains Informasi Geografi, Fakultas Geografi, Universitas Gadjah Mada, Jalan \\ Kaliurang, Bulaksumur, Yogyakarta 55281.
}

*Penulis korespondensi. Tel: +6281229819298. Email: primawidayani@ugm.ac.id.

Diterima: 26 Desember 2016

Disetujui: 5 Mei 2017

\begin{abstract}
Abstrak
Malaria merupakan salah satu penyakit menular endemis yang masih menjadi perhatian khusus pada kesehatan masyarakat di Indonesia, salah satunya di Kabupaten Purworejo. Tahun 2013, terdapat 615 kasus kejadian penyakit malaria pada semua rentang umur di kabupaten ini. Penanganan penyakit ini dilakukan dengan beberapa cara, contohnya adalah dengan surveilans malaria. Kegiatan surveilans bermaksud untuk melaksanakan tindakan penanggulangan yang cepat dan akurat disesuaikan dengan kondisi setempat. Salah satu tujuan kegiatan ini untuk mendapatkan gambaran distribusi penyakit malaria yang dapat dilakukan dengan pembuatan peta kerawanan penyakit malaria. Tujuan dari penelitian ini adalah menentukan kerawanan wilayah terhadap penyakit malaria dengan metode Spatial Multicriteria Analysis (SMCA). Penelitian ini memanfaatkan data Citra Landsat 8 dan beberapa data sekunder yang diolah dengan menggunakan software ILWIS. Hasil dari penelitian ini menunjukan bahwa metode SMCA dapat memetakan kerawanan penyakit malaria dan terdapat enam kecamatan di Kabupaten Purworejo yang rawan, yaitu Kecamatan - kecamatan Bruno, Bener, Gebang, Loano, Kaligesing, dan Bagelen.
\end{abstract}

Kata Kunci : kerawanan, lingkungan, malaria, peta, spatial multicriteria analysis.

\begin{abstract}
Malaria is one of endemic infectious disease that has been special concern in Indonesian public health, especially in Purworejo Regency. In 2013, there were 615 incident cases of malaria disease in all age ranges. There are several kinds of handling malaria disease, one of which is malaria surveillances. Surveillances activity intends to implement handling fast and accurate actions. One of this activity aims to obtain overview distribution of malaria disease which can be done with vulnerable mapping. This study aims to determine vulnerability of area with malaria disease using Spatial Multicriteria Analysis (SMCA). It has been done by utilizing Landsat 8 Imagery data and some of secondary data processing with ILWIS software. The result of this study showed that SMCA methods can be used to vulnerability mapping of malaria disease and found that there are six vulnerable districts, Bruno, Bener, Gebang, Loano, Kaligesing, and Bagelen District.
\end{abstract}

Keywords: environment, vulnerability, malaria, map, spatial multicriteria analysis.

\section{PENDAHULUAN}

Perkembangan teknologi penginderaan jauh semakin pesat seiring dengan hadirnya berbagai aplikasi penginderaan jauh di berbagai bidang termasuk di bidang kesehatan. Aplikasi di bidang kesehatan menggunakan data penginderaan jauh sudah dimulai sejak tahun 1970 yaitu dengan diterbitkannya artikel yang membahas tentang perkembangan aplikasi penginderaan jauh untuk kesehatan, salah satunya adalah program Health Application Office (HAO) yang dikembangkan oleh NASA tahun 1970-1976. Program ini melakukan investigasi dari jarak dekat mengenai penyakit. Saat ini program HAO NASA sudah tidak berjalan lagi, namun NASA masih melakukan dukungan data untuk lembaga yang bergerak di bidang kesehatan seperti The Centers for Disease Control and Prevention atau CDC (Clennon dkk, 2010).

Hingga saat ini penelitian penginderaan jauh di bidang kesehatan makin berkembang seiring dengan jumlah penyakit yang banyak berkembang di masyarakat dan yang dipengaruhi oleh faktor lingkungan. Salah satu penyakit yang marak diteliti dengan bantuan data penginderaan jauh adalah penyakit malaria. Dengan data penginderaan jauh, kondisi lingkungan dapat diekstraksi dan diturunkan menjadi beberapa fakor lingkungan yang berpengaruh terhadap perkembangbiakan nyamuk Anopheles. Citra penginderaan jauh mampu menyajikan data tutupan lahan, vegetasi dan daerah genangan air yang berpotensi menjadi tempat perindukan nyamuk penyebab malaria (Tran, 2008). 
Malaria sebagai salah satu penyakit menular, sampai saat ini masih menjadi masalah kesehatan masyarakat. Penyakit ini tidak hanya menimbulkan gangguan kesehatan di masyarakat, tetapi juga menyebabkan kematian, selain menurunkan produktivitas kerja dan dampak ekonomi lainnya (Bhattacharya dan Datta, 2006). Diduga 36\% penduduk dunia terkena resiko malaria (Anonim, 2010). Di negara berkembang, termasuk Indonesia meningkatnya malaria sangat berkaitan erat dengan kekurangan gizi, krisis ekonomi, perang atau kerusuhan. Kejadian penyakit malaria cukup tinggi di provinsi Aceh (Thaharuddin dkk., 2004), Papua (Watofa dkk., 2017) dan juga terjadi di Provinsi Jawa Tengah. Kasus malaria di Jawa Tengah tidak mengalami penurunan jumlah dan terjadi di beberapa kabupaten termasuk Kabupaten Purworejo (Anonim, 2014). Pada tahun 2006 hingga 2010 kejadian kasus malaria di Kabupaten Purworejo cukup tinggi dan stagnan pada kisaran angka 440-372 kasus per tahun. Angka ini kemudian mengalami kenaikan yang sangat signifikan pada tahun 2011, yaitu 1001 kasus malaria. Kemudian pada tahun 2012 kejadian penyakit malaria menurun hingga angka 500 dan kembali naik pada tahun 2013. Jumlah kejadian malaria yang fluktuatif ini menunjukkan bahwa upaya yang dilakukan oleh pemerintah Kabupaten Purworejo untuk menekan angka kesakitan malaria masih belum efektif (Anonim, 2014).

Upaya penanggulangan malaria oleh Pemerintah Kabupaten Purworejo telah banyak dilakukan, baik pada penanganan penyakitnya maupun vektornya. Pengendalian malaria di Kabupaten Purworejo membutuhkan suatu gerakan dari masyarakat yang bersifat jangka panjang, mudah, terjangkau, bermanfaat dan aman terhadap lingkungan.

Sebagai salah satu upaya untuk mengetahui lokasi yang memiliki tingkat risiko tinggi secara spasial adalah dengan pemetaan wilayah berdasarkan kondisi fisiknya dan ditunjang dengan data kejadian penyakit malaria. Hal ini juga telah berhasil dilakukan oleh Poncon dkk (2008) untuk pemetaan Anopheles hyrcanus di Perancis dan oleh Hongoh (2011) untuk analisis pengelolaan penyakit vector-bourne. Pembuatan peta kerentanan malaria sudah banyak dilakukan oleh para peneliti terdahulu dengan menggunakan metode overlay berjenjang tertimbang dan metode matching, namun penggunaan metode Spatial Multi Criteria Analysis (SMCA) masih belum banyak dilakukan. Berdasarkan permasalah tersebut, maka dilakukan penelitian untuk menentukan daerah rawan penyakit malaria dengan menggunakan metode SMCA di Kabupaten Purworejo. Penelitian ini bertujuan untuk menentukan daerah mana saja yang rawan terhadap penyakit malaria dengan menyajikannya pada peta kerawanan wilayah terhadap penyakit malaria di Kabupaten Purworejo.

\section{METODE PENELITIAN}

\section{Waktu dan Lokasi}

Kegiatan penelitian ini dilakukan pada tahun 2014 dan dilaksanakan di Kabupaten Purworejo meliputi seluruh kecematan. Kabupaten ini memiliki 16 kecamatan, yaitu Kecamatan Bagelen, Banyuurip, Bener, Bayan, Bruno, Butuh, Gebang, Grabag, Kaligesing, Kemiri, Kutoarjo, Loano, Ngombol, Pituruh, Purwodadi, dan Purworejo.

\section{Bahan dan Alat}

Penelitian ini menggunakan bahan penelitian berupa Citra satelit Landsat 8 untuk memperoleh data penggunaan lahan dan tutupan vegetasi. Peta Rupa Bumi Indonesia skala 1 : 25.000 digunakan untuk koreksi geometri citra dan sebagai peta dasar. Data lain yang dibutuhkan dalam penelitian ini, yaitu data iklim yang berupa curah hujan dan kelembaban. Untuk menguji hasil digunakan data kejadian malaria yang dipeoleh dari Dinas Kesehatan setempat (Anonim, 2014). Jenis dan teknik pengolahan data dilakukan seperti diringkas pada Tabel 1.

Tabel 1. Jenis dan teknik pengolahan data

\begin{tabular}{|c|c|c|c|c|c|}
\hline \multirow[b]{2}{*}{ No. } & \multirow[b]{2}{*}{ Jenis data } & \multicolumn{3}{|c|}{ Sumber data } & \multirow[b]{2}{*}{ Teknik pengolahan data } \\
\hline & & $\begin{array}{l}\text { Citra } \\
\text { satelit } \\
\text { Landsat }\end{array}$ & $\begin{array}{l}\text { Data } \\
\text { lain/data } \\
\text { sekunder }\end{array}$ & $\begin{array}{l}\text { Survei } \\
\text { lapangan }\end{array}$ & \\
\hline 1. & Kerapatan vegetasi & $\sqrt{ }$ & & $\sqrt{ }$ & $\begin{array}{l}\text { Transformasi NDVI dan survai } \\
\text { lapangan }\end{array}$ \\
\hline 2. & Curah hujan & & $\sqrt{ }$ & & Interpolasi \\
\hline 3. & Kelembaban & & $\sqrt{ }$ & $\sqrt{ }$ & Interpolasi dan survai lapangan \\
\hline 4. & Penggunaan lahan & $\sqrt{ }$ & & $\sqrt{ }$ & Interpretasi visual dan cek lapangan \\
\hline 5. & Tekstur tanah & $\sqrt{ }$ & $\sqrt{ }$ & $\sqrt{ }$ & $\begin{array}{l}\text { Interpretasi visual dengan didukung } \\
\text { peta tanah dan survai lapangan }\end{array}$ \\
\hline 6. & Ketinggian & & $\sqrt{ }$ & $\sqrt{ }$ & Interpolasi dan cek lapangan \\
\hline
\end{tabular}


Alat penelitian yang digunakan pada penelitian ini berupa seperangkat komputer untuk pengolahan data. Perangkat lunak ILWIS digunakan untuk mengolah data dengan metode SMCA. Printer warna untuk cetak citra dan petapeta tematik serta perangkat survey lapangan (GPS, kamera).

\section{Prosedur}

Survei lapangan dilakukan untuk mencocokkan hasil ekstraksi informasi dari citra satelit dengan kondisi di lapangan yang dilakukan dengan sampel berdasarkan metode stratified random sampling. Pada penelitian ini diambil sampel sejumlah 35 titik.

Penelitian dengan menggunakan metode SMCA diawali dengan menentukan fokus penelitian, termasuk hasil yang diharapkan, tujuan dan obyek. Kemudian dari hasil fokus penelitian yang sudah ditentukan, dilakukan identifikasi faktor-faktor yang digunakan dalam penelitian, termasuk di dalamnya menggolongkan pengaruh faktor tersebut terhadap hasil yang akan dikerjakan apakah sebagai pendukung atau penghambat. Langkah selanjutnya adalah penilaian, standarisasi dan pembobotan faktor-faktor yang digunakan hingga pada akhirnya menghasilkan peta kesesuaian.

Penyusunan penelitian untuk menentukan kerawanan penyakit terhadap malaria menggunakan beberapa faktor yang dapat dikelompokan menjadi 2 yaitu faktor fisik lahan dan faktor iklim, di mana faktor fisik lahan meliputi penggunaan lahan, tekstur tanah, kerapatan vegetasi dan ketinggian. Untuk faktor iklim meliputi curah hujan dan kelembapan. Skema pohon faktor yang dilakukan pada penelitian kali ini dapat dilihat pada Gambar 1 .

Pembuatan SMCA dapat dilakukan dengan menyusun skenario kemungkinan-kemungkinan besar nilai hubungan setiap parameter terhadap kejadian. Penyusunan skenario tersebut dapat dilihat pada Tabel 2.

\section{HASIL DAN PEMBAHASAN}

Sembilan model yang dihasilkan dari skenario yang dibuat sebelumnya menunjukkan adanya perbedaan tingkat kerawanan pada masing-masing daerah dan bervariasi setiap modelnya. Pada penelitian kali ini, dilakukan dua tahapan untuk melihat daerah mana saja yang memiliki kerawanan tinggi dan model dengan skenario seperti apa yang sesuai dengan kondisi kejadian malaria di Kabupaten Purworejo.

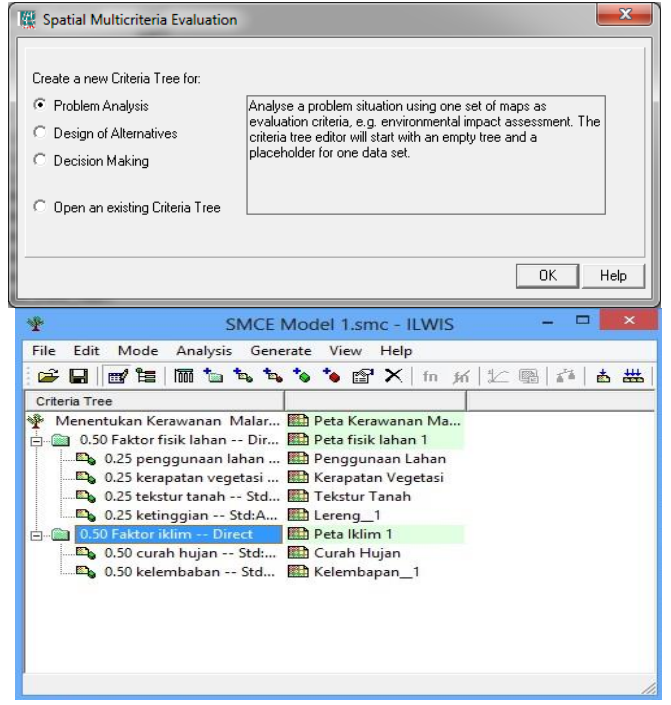

Gambar 1. Pohon skema kerawanan penyakit malaria.

\section{Model kerawanan malaria berdasarkan kecenderungan kehadiran}

Kecenderungan daerah-daerah yang tetap menjadi wilayah rawan ketika standarisasi dan bobot parameter fisik lingkungan dan iklimnya diubah-ubah, berdasarkan kemungkinan-kemungkinan besar pengaruh faktor - faktor lingkungan terhadap kejadian penyakit malaria akan menunjukkan di mana daerah yang selalu muncul sebagai daerah rawan penyakit. Apabila dilihat dari hasil pembuatan model kerawanan dengan sembilan skenario, wilayah yang tetap bertahan menjadi daerah rawan adalah Kecamatan Bruno, Kecamatan Gebang dan Kecamatan Bener, sehingga wilayah ini yang ditetapkan menjadi daerah rawan malaria. Untuk wilayah yang selalu menjadi wilayah agak rawan adalah Kecamatan Loano dan Kecamatan Kaligesing, sementara Kecamatan Gebang, Kecamatan Pituruh dan Kecamatan Kemiri sebagian wilayahnya menjadi daerah yang agak rawan dan tidak rawan. Kecamatan yang konsisten menjadi daerah tidak rawan adalah Kecamatan Purworejo, sedangkan kecamatan yang lainnya bervariasi.

Berdasarkan pembuatan 9 skenario model kerawanan wilayah terhadap penyakit malaria ini dapat ditentukan daerah prioritas penanganan, di mana daerah rawan ditentukan dari konsistensi kemunculan wilayah tersebut sebagai daerah rawan di setiap model. Hasil pembuatan model kerawanan wilayah terhadap penyakit malaria dengan sembilan skenario model dapat dilihat pada Gambar 3.

\section{Model kerawanan malaria berdasarkan keberadaan kasus}

Peta kerawanan malaria yang dibuat menggunakan SMCA dengan 9 skenario model dapat divalidasi menggunakan keberadaan kasus 
malaria yang memang berasal dari wilayah tersebut (bukan kasus impor). Model yang sesuai adalah model 7 dan model 2. Pada kedua model tersebut terlihat bahwa wilayah rawan malaria terletak pada daerah perbukitan di sebelah utara dan timur Kabu paten Purworejo. Jika dilihat dari batas administrasi, yang merupakan daerah rawan malaria adalah Kecamatan Bruno, Kecamatan Gebang, Kecamatan Bener, Kecamatan Loano dan

Tabel 2. Skenario pembuatan SMCA.

\begin{tabular}{|c|c|c|c|c|c|}
\hline Skenario & Nama peta hasil & Grup & $\begin{array}{l}\text { Bobot } \\
\text { Grup }\end{array}$ & Parameter & $\begin{array}{c}\text { Bobot } \\
\text { parameter }\end{array}$ \\
\hline \multirow[t]{6}{*}{1} & Peta Kerawanan & Faktor fisik lahan & 0,50 & Penggunaan lahan & 0,25 \\
\hline & Malaria 1 & & & Kerapatan vegetasi & 0,25 \\
\hline & & & & Tektur tanah & 0,25 \\
\hline & & & & Ketinggian & 0,25 \\
\hline & & Faktor iklim & 0,50 & Curah hujan & 0,50 \\
\hline & & & & Kelembaban & 0,50 \\
\hline \multirow[t]{6}{*}{2} & Peta Kerawanan & Faktor fisik lahan & 0,75 & Penggunaan lahan & 0,25 \\
\hline & Malaria 2 & & & Kerapatan vegetasi & 0,25 \\
\hline & & & & Tektur tanah & 0,25 \\
\hline & & & & Ketinggian & 0,25 \\
\hline & & Faktor iklim & 0,25 & Curah hujan & 0,50 \\
\hline & & & & Kelembaban & 0,50 \\
\hline \multirow[t]{6}{*}{3} & Peta Kerawanan & Faktor fisik lahan & 0,25 & Penggunaan lahan & 0,25 \\
\hline & Malaria 3 & & & Kerapatan vegetasi & 0,25 \\
\hline & & & & Tektur tanah & 0,25 \\
\hline & & & & Ketinggian & 0,25 \\
\hline & & Faktor iklim & 0,75 & Curah hujan & 0,50 \\
\hline & & & & Kelembaban & 0,50 \\
\hline \multirow[t]{6}{*}{4} & Peta Kerawanan & Faktor fisik lahan & 0,50 & Penggunaan lahan & 0,70 \\
\hline & Malaria 4 & & & Kerapatan vegetasi & 0,10 \\
\hline & & & & Tektur tanah & 0,10 \\
\hline & & & & Ketinggian & 0,10 \\
\hline & & Faktor iklim & 0,50 & Curah hujan & 0,50 \\
\hline & & & & Kelembaban & 0,50 \\
\hline \multirow[t]{6}{*}{5} & Peta Kerawanan & Faktor fisik lahan & 0,50 & Penggunaan lahan & 0,10 \\
\hline & Malaria 5 & & & Kerapatan vegetasi & 0,70 \\
\hline & & & & Tektur tanah & 0,10 \\
\hline & & & & Ketinggian & 0,10 \\
\hline & & Faktor iklim & 0,50 & Curah hujan & 0,50 \\
\hline & & & & Kelembaban & 0,50 \\
\hline \multirow[t]{6}{*}{6} & Peta Kerawanan & Faktor fisik lahan & 0,50 & Penggunaan lahan & 0,10 \\
\hline & Malaria 6 & & & Kerapatan vegetasi & 0,10 \\
\hline & & & & Tektur tanah & 0,70 \\
\hline & & & & Ketinggian & 0,10 \\
\hline & & Faktor iklim & 0,50 & Curah hujan & 0,50 \\
\hline & & & & Kelembaban & 0,50 \\
\hline \multirow[t]{6}{*}{7} & Peta Kerawanan & Faktor fisik lahan & 0,50 & Penggunaan lahan & 0,10 \\
\hline & Malaria 7 & & & Kerapatan vegetasi & 0,10 \\
\hline & & & & Tektur tanah & 0,10 \\
\hline & & & & Ketinggian & 0,70 \\
\hline & & Faktor iklim & 0,50 & Curah hujan & 0,50 \\
\hline & & & & Kelembaban & 0,50 \\
\hline \multirow[t]{6}{*}{8} & Peta Kerawanan & Faktor fisik lahan & 0,50 & Penggunaan lahan & 0,25 \\
\hline & Malaria 8 & & & Kerapatan vegetasi & 0,25 \\
\hline & & & & Tektur tanah & 0,25 \\
\hline & & & & Ketinggian & 0,25 \\
\hline & & Faktor iklim & 0,50 & Curah hujan & 0,80 \\
\hline & & & & Kelembaban & 0,20 \\
\hline \multirow[t]{6}{*}{9} & Peta Kerawanan & Faktor fisik lahan & 0,50 & Penggunaan lahan & 0,25 \\
\hline & Malaria 8 & & & Kerapatan vegetasi & 0,25 \\
\hline & & & & Tektur tanah & 0,25 \\
\hline & & & & Ketinggian & 0,25 \\
\hline & & Faktor iklim & 0,50 & Curah hujan & 0,20 \\
\hline & & & & Kelembaban & 0,80 \\
\hline
\end{tabular}




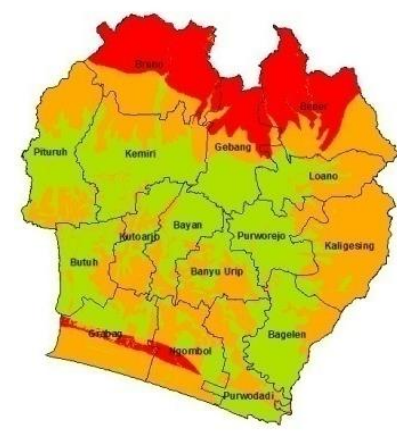

Model 1

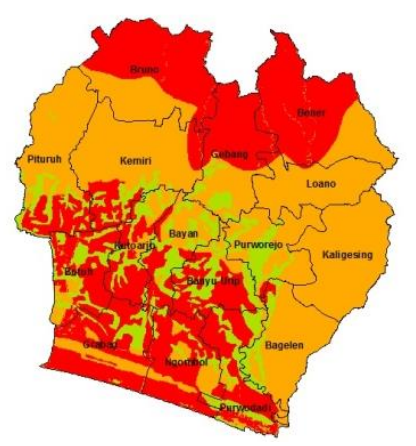

Model 4

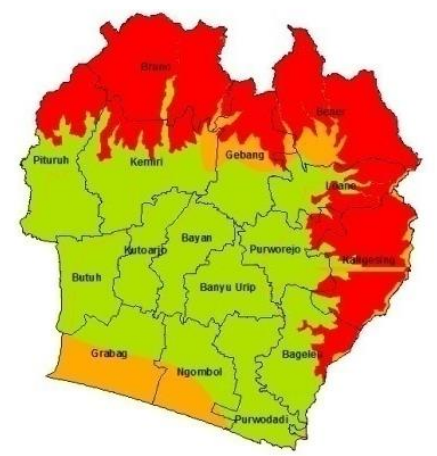

Model 7

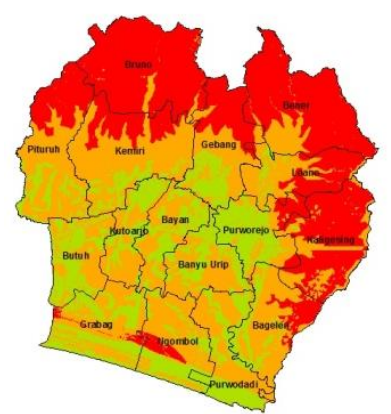

Model 2

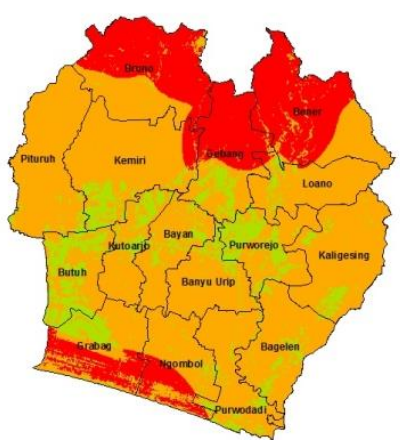

Model 5

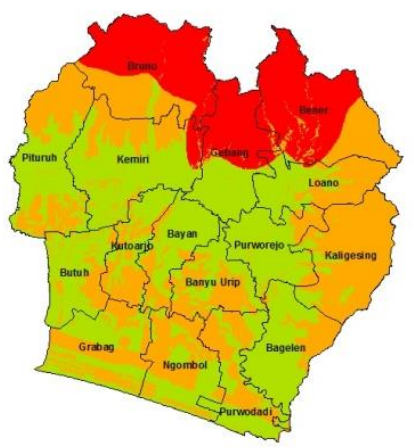

Model 8

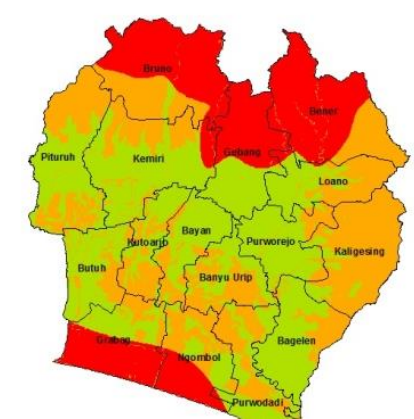

Model 3

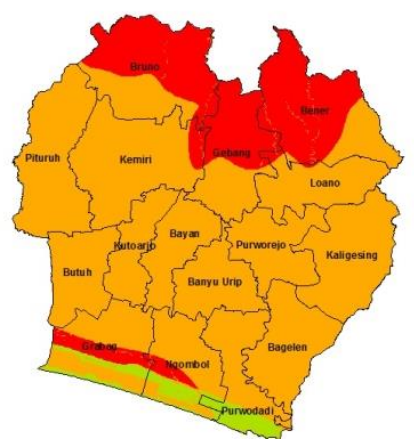

Model 6

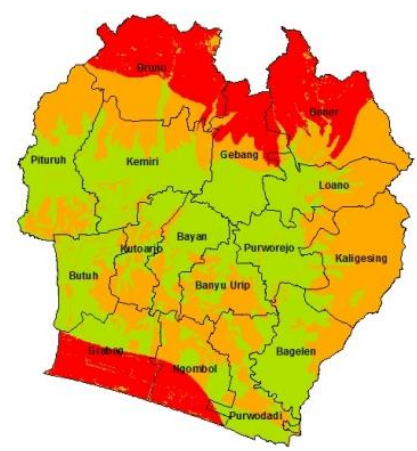

Model 9

Keterangan :

\begin{tabular}{|ll|}
\hline & Rawan \\
$\square$ & Agak rawan \\
$\square$ & Tidak Rawan \\
\hline
\end{tabular}

Gambar 3. Hasil pemodelan kerawanan malaria dengan 9 model.

Kecamatan Kaligesing. Sedangkan jika dilihat dari persebaran kasusnya, wilayah ini merupakan wilayah yang banyak terjangkit penyakit malaria. Kasus malaria pada peta Gambar 4 yang disimbolkan dengan titik berwarna biru, di mana mewakili satu kasus kejadian penyakit malaria.

Model 7 menggunakan skenario pembobotan sebagai berikut : faktor fisik lahan diberi bobot 0,50 dan faktor iklim 0,25. Parameter penggunan lahan, kerapatan vegetasi, tekstur tanah dan ketinggian diberi bobot 0,25, sedangkan curah hujan dan kelembaban diberi bobot 0,50. Model 2 menggunakan skenario sebagai berikut faktor fisik lahan dan faktor iklim diberi bobot 0,50. Parameter penggunan lahan, kerapatan vegetasi, tekstur tanah diberi bobot 0,10 dan ketinggan diberi bobot 70 , sedangkan curah hujan dan kelembaban diberi bobot 0,50 . 

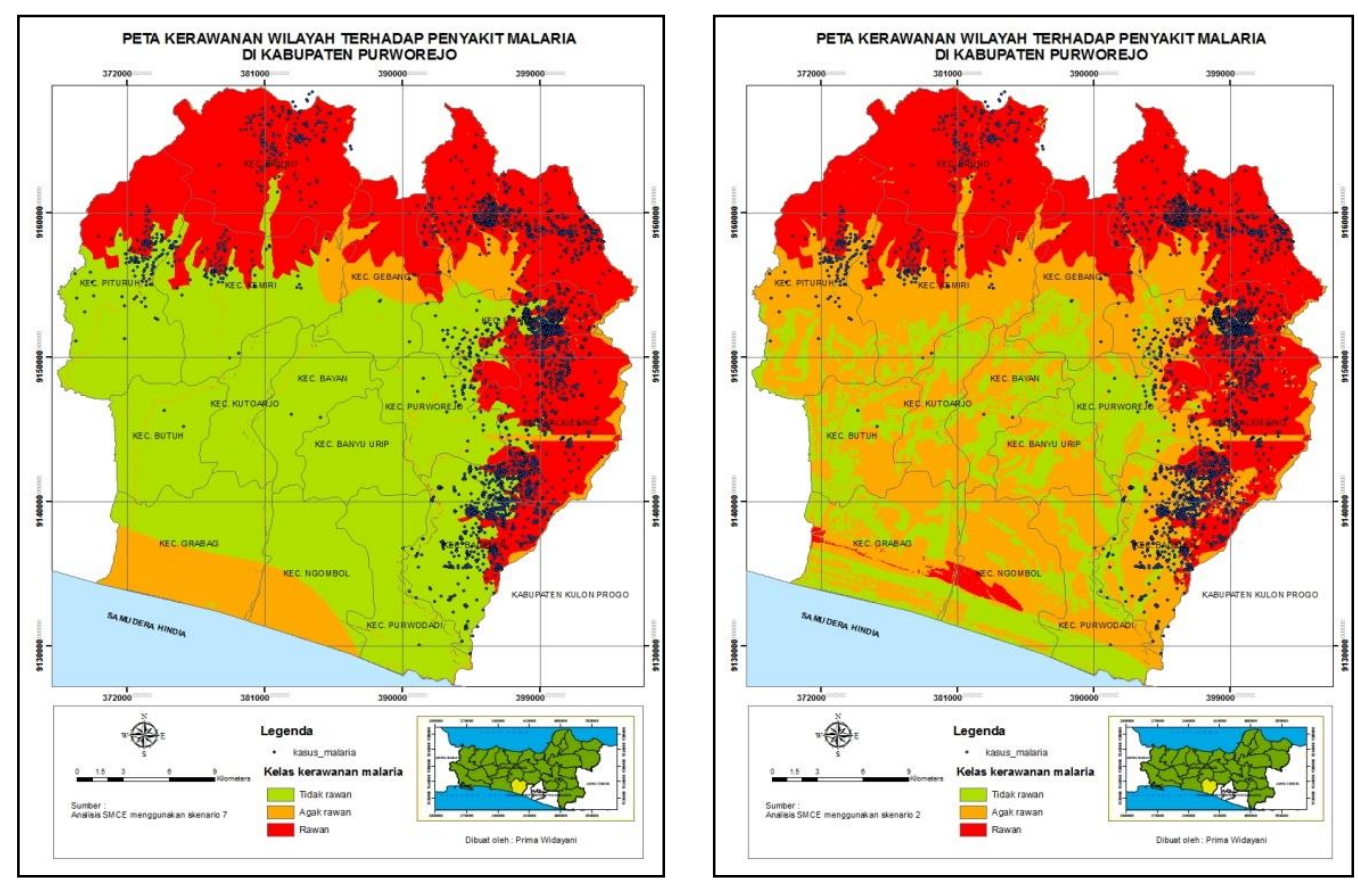

Gambar 4. Peta Kerawanan Malaria dengan skenario 7 dan 2.

Kedua model dengan skenario terbaik yang telah dibuat menunjukkan indikasi bahwa faktor ketinggian tempat memiliki pengaruh yang kuat terhadap kejadian malaria di Kabupaten Purworejo. Ketinggian tempat berkorelasi dengan faktor iklim seperti suhu dan kelembaban. Ketinggian tempat juga berpengaruh terhadap penggunaan lahan, di mana penggunaan lahan di wilayah yang tinggi didominasi oleh hutan dan kebun campuran. Wilayah dengan suhu berkisar atara $25-30{ }^{\circ} \mathrm{C}$ dengan kelembaban antara $>60 \%$ dengan kondisi tutupan lahan didominasi vegetasi merupakan tempat yang baik untuk peristirahatan nyamuk, sehingga daerah ini banyak terdapat kejadian malaria.

Wilayah yang kurang rawan posisinya berada di bagian atas dan tengah Kabupaten Purworejo yang merupakan dataran. Untuk wilayah yang tidak rawan berada di bagian tengah dan selatan. Nyamuk Anopheles yang berada di wilayah Kabupaten Purworejo tidak hanya jenis yang hidup di wilayah perbukitan saja, tetapi juga di daerah pesisir yaitu Anopheles sundaicus. Jika dilihat dari model kerawanan, wilayah pesisir juga rawan terhadap malaria karena keberadaan nyamuk $A$. sundaicus ini, namun kasus memang tidak diketemukan di dareh pesisir, sehingga walaupun tidak ada kasus, daerah ini tetap dinyatakan sebagai daerah yang rawan malaria.

Sembilan model yang dibuat berdasarkan skenario dan ditampalkan dengan kejadian penyakit malaria di Kabupaten Purworejo dapat dilihat pada Gambar 5. Sebagaimana yang sudah dijabarkan sebelumnya bahwa model 2 dan model 7 merupakan model terbaik karena sesuai dengan kondisi kerawanan penyakit yang ada. Sedangkan model yang lain tidak, seperti yang dapat dilihat pada model 1 , model 3 , model 4 , model 5 dan model 6 daerah dengan kerawanan penyakit sedang pada model tidak sesuai dengan jumlah kejadian penyakit yang ada, yang terjadi di Kecamatan Bagelen, Kecamatan Kaligesing, Kecamatan Loano dan sebagian Kecamatan Bener. Sedangkan untuk model 8 dan model 9 kejadian penyakit malaria berada pada daerah dengan kerawanan rendah hingga sedang pada kecamatan yang sama.

\section{Penggunaan SMCA}

Multi Criteria Analysis (MCA) adalah metode pengambilan keputusan untuk tujuan tertentu dengan jalan menganalisis beberapa variabel yang berpengaruh (Wibowo dan Semedi, 2011). Proses yang ada dalam MCA termasuk penentuan variabel paling dominan serta perhitungan bobot agar dihasilkan hasil yang sesuai. Saat ini multi criteria analysis sudah terintegrasi dengan analisis spasial yang mampu menganalisis variabel-variabel yang berbeda dengan mempertimbangkan aspek spasialnya. Pada awalnya MCA hanya merupakan analisis statistik, namun sekarang analisis tersebut sudah dikembangkan dengan memperhatikan aspek spasial sehingga analisis tersebut kemudian disebut dengan SMCA.

Proses yang dilakukan pada SMCA adalah penentuan fokus atau tujuan, pada penelitian ini tujuannya adalah menentukan daerah yang rawan 

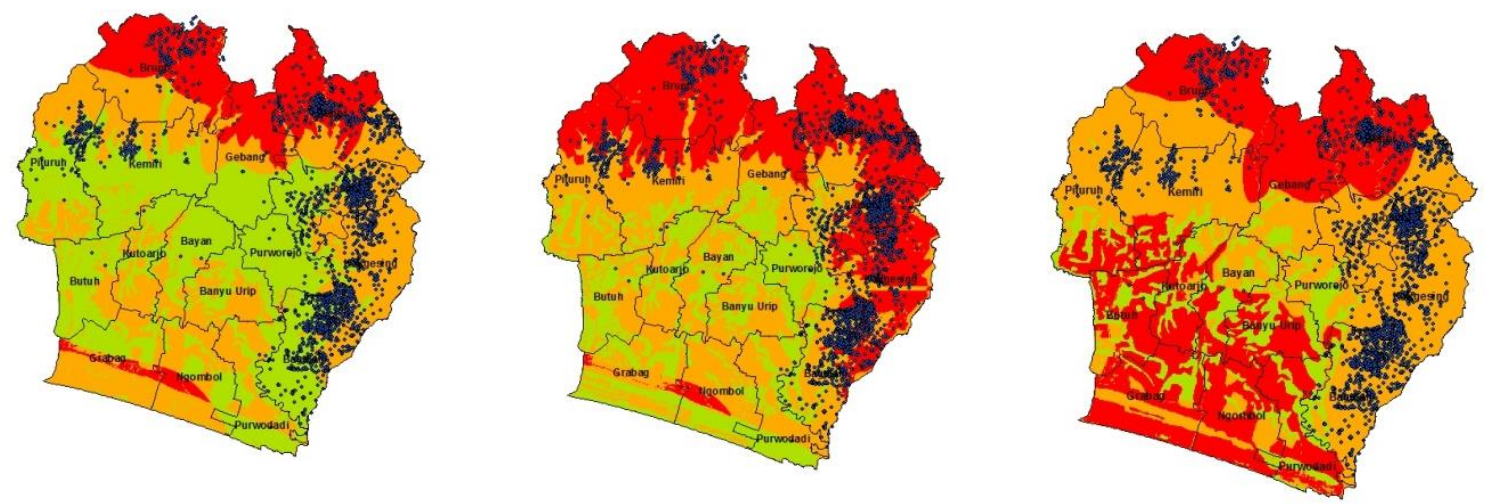

Model 1

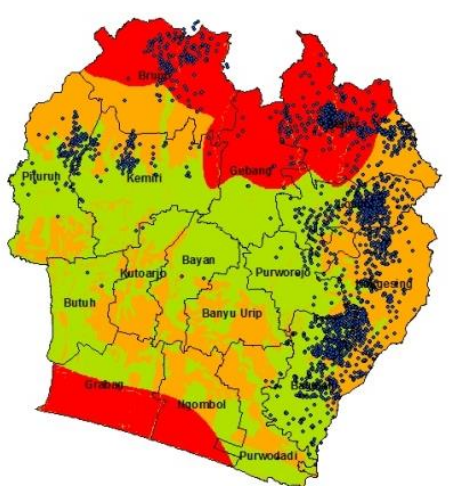

Model 4

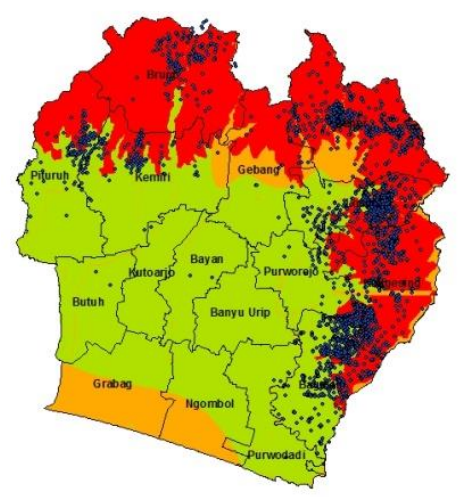

Model 7
Model 2

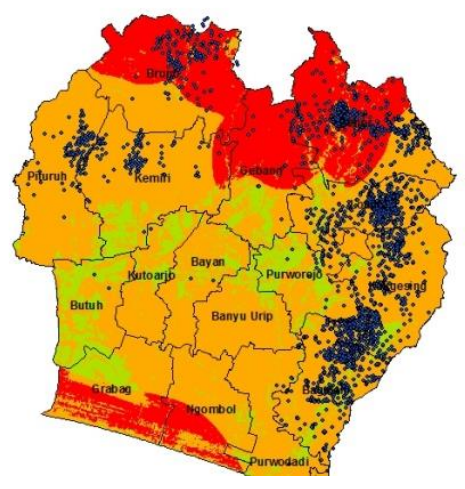

Model 5

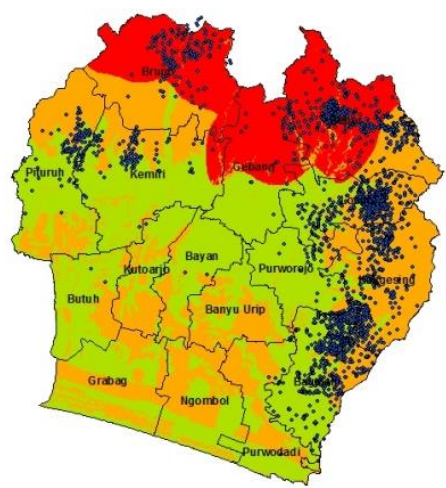

Model 8
Model 3

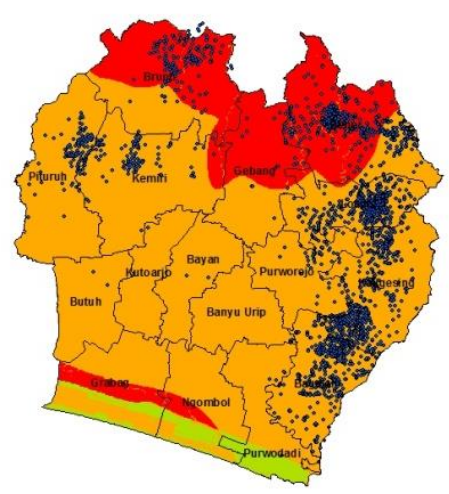

Model 6

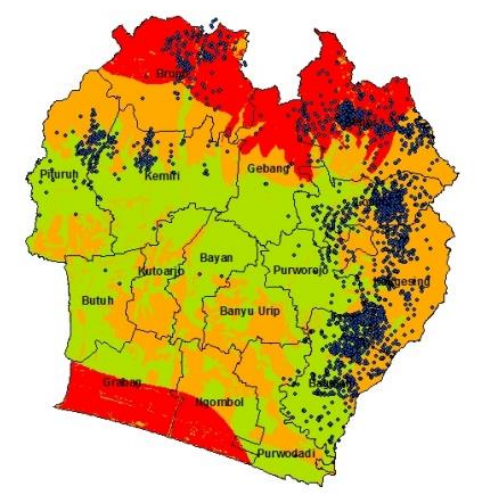

Model 9

Keterangan :

Rawan kasusomalaria

Agak rawan

Tidak Rawan

Gambar 5. Peta kerawanan malaria dengan kasus.

malaria di Kabupaten Purworejo. Kriteria yang digunakan adalah faktor fisik lahan dan faktor iklim. Faktor fisik lahan meliputi penggunaan lahan, kerapatan vegetasi, ketinggian dan tekstur tanah, sedangkan faktor iklim meliputi curah hujan dan kelembaban. Faktor ini dipilih karena hubungannya dengan habitat dan keberadaan nyamuk Anopheles. Masing-masing aspek diberikan nilai atau skor sesuai dengan besar pengaruh terhadap keberadaan nyamuk. Kelebihan 
dari SMCA ini terdapat standarisasi skor yang dapat dipilih metodenya. Selanjutnya akan diberikan bobot pada tiap aspek. Hasil akhir adalah muncul peta yang diminta atau yang sesuai dengan tujuannya (Meng dkk, 2011). Kelebihan analisis ini adalah mampu melakukan analisis dengan kriteria yang banyak dan dapat dikelompokkan menurut jenis kriteria dan aspeknya, bisa berupa aspek fisik maupun sosial ekonomi.

\section{KESIMPULAN}

Kesimpulan yang didapatkan dari penelitian ini adalah, Kabupaten Purworejo memiliki 6 kecamatan yang rawan malaria yaitu Kecamatan Bruno, Bener, Gebang, Loano, Kaligesing dan Bagelen, baik dengan melihat pengulangan kehadiran daerah rawan ataupun dengan kehadiran kasus pada model. Lebih jauh lagi, Spatial Multi Criteria Analysis dapat digunakan untuk membuat peta kerawanan wilayah terhadap penyakit malaria.

\section{DAFTAR PUSTAKA}

Anonim, 2010. Malaria. Who Report on Global Surveillance of Epidemic-prone Infectious Diseases. Website : http://www.who.int/csr/ resources/publications/surveillance/CSR_ISR_ 2000_1web/en/. Diakses pada : April 2009.

Anonim, 2014. Data Penderita Malaria Kabupaten Purworejo. Laporan Tahunan. Departemen Kesehatan RI : Jakarta.

Bhattacharya, S., dan Datta, D., 2006. Effects of Economic Behaviour and People Migrantion on The Epidemiology of Malaria : A Model Based Study. J. Manusia \& Lingkungan, 13(3):101-111.

Hongoh, V., Hoen, A.G., Aenishaensin, C., Waaub, J.P., Belanger, D., dan Michel, P., 2011. Spatially Explicit Multi Criteria Decision
Analysis for Managing Vector Born Diseases International Journal of Health Geographics.10:70.

Clennon, J.S., Kamangan, A., Musapa, M., Shiff, C., dan Glass, G.E., 2010, Identifyng Malaria Vector Breeding Habitats With Remote Sensing data and Terrain Based Landsacape Indices in Zambia, International Journal of Helath Geographic, 9:58.

Meng, Y., Qian, Y., Zhang, Y; Sheng, J ; Shen, D., dan Ge, Y., 2011. Spatial Multicriteria Decision Analysis of Flood Risks in AgingDam Management in China: A Framework and Case Study. International Journal of Environmental Research and Public Health, 8(5):1368-1387.

Ponçon, N., Toty, C., Linard, C., Guis, H., Ferré, J.B., Seen, D.L., Roger, F., de la Rocque, S., Fontenille, D., dan Baldet, T., 2008, Using Remote Sensing to Map Larval and Adult Populations of Anopheles hyrcanus (Diptera: Culicidae) a Potential Malaria Vector in Southern France, International Journal of Health Geographics. 7:9.

Thaharuddin, Soeyoko, dan Sutomo, A.H., (2004). Lingkungan Perumahan, Kondisi Fisik, Tingkat Pengetahuan, Perilaku Masyarakat dan Angka Kejadian Malaria di Kota Sabang. J. Manusia \& Lingkungan, 11(3):126-133.

Watofa, A.F. Husodo, A.H. Sudarmadji dan Setiani, O., 2017. Risiko Lingkungan Fisik Terhadap Kejadian Malaria di Wilayah Danau Sentani, Kabupaten Jayapura, Provinsi Papua. J. Manusia \& Lingkungan, 24(1):31-38.

Wibowo, A., dan Semedi, J.M., 2011. Model Spasial dengan SMCE Untuk Kesesuian Kawasan Industri (Studi Kasus di Kota Serang). Globe, 13(1):50-59. 